\title{
MENJADIKAN POTENSI DIRI SEBAGAI ASET INVESTASI PAHALA
}

\author{
Muh. Haris Zubaidillah \\ Email:hariszub@gmail.com
}

Allah SWT Yang Maha Kuasa menciptakan manusia sebagai makhluk yang sempurna, yaitu dengan dikaruniakannya akal untuk berfikir dan mengendalikan segala aktifitasnya. Allah SWT Maha Pemurah telah menentukan dan menetapkan karunianya kepada hambanya, sehingga setiap makhluk yang hidup, baik binatang, tumbuhan ataupun manusia, semuanya merasakan nikmat-Nya. Allah SWT dengan bijaksana-Nya menempatkan manusia pada kedudukan masing-masing, ada yang ditempatkan dalam bidang usaha (kasab/asbab) dan ada yang ditempatkan di bidang Tajrid (ibadah melulu).

Adapun yang dimaksud dengan bidang-bidang usaha adalah usaha manusia untuk mencapai ridha Allah, tetapi dengan adanya asbab, dia masih harus mencari kebutuhan duniawi dan manusiawi, tetapi setelah berhasil, dia gunakan untuk menjalankan kewajibannya sebagai hamba Allah yang beriman, seperti menjadi seorang guru yang kesehairannya adalah mengajar, seorang pedagang, petani, nelayan dan pegawai yang kesehariannya hanya bergulat dalam mencari rejeki, seorang pejabat yang kesehariannya sibuk dengan urusan pemerintahannya, seorang pelajar, santri dan 
mahasiswa yang aktifitasnya adalah belajar, diskusi, penelitian, dan lain-lain. Tetapi mereka tidak lupa terhadap kewajiban - kewajiban hidup di tengah-tengah masyarakt. Seperti membantu anak-anak yatim, fakir miskin, pembangunan masjid dan pendidikan.

Adapun yang dimaksud dengan bidang tajrid adalah dimana manusia hanya mengabdi melulu kepada Allah tanpa menghiraukan urusan dunia, disebabkan kebutuhan duniawinya sudah terpenuhi.

Dalam hal ini, Syaikh Ibnu Athaillah dalam kitab Hikam berkata:

$$
\begin{aligned}
& \text { إرادتُكَ التجريدَ مع إقامِة الله إِيَّكَ في الأسباب من الشَّهوة الخفيةِ }
\end{aligned}
$$

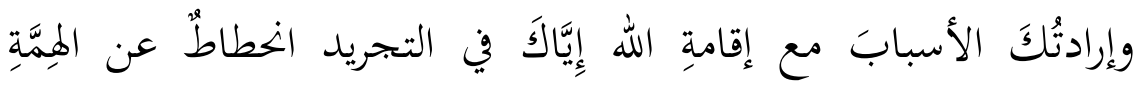

"Keinginanmu untuk bertajrid (melulu beribadah tanpa menghiraukan duniawi) padahal Allah menjadikanmu pada golongan yang berusaha (asbab), maka kemauan yang seperti itu termasuk kemauan hawa nafsu yang samar (halus). Sebaliknya keinginanmu dalam berusaha (untuk memenuhi duniawi) padahal Allah menjadikanmu dalam golongan tajrid, maka keinginan yang seperti itu berarti suatu kemunduran dari semangat cita-cita ang luhur"

Orang yang berada di bidang usaha tapi ia menginginkan untuk bertajrid (melulu hanya beribadah), padahal kedudukannya adalah di bidang usaha, maka kemauan yang demikian itu adalah dorongan nafsu yang 
samar dan halus, karena ingin dianggap sebagai manusia yang zuhud yakni orang yang tidak rakus kepada dunia dan ikhlas beramal, sehingga mendapat kasih sayang Allah dan menimbulkan kepercayaan dari sesama manusia.

Demikian juga sebaliknya bagi orang yang ditetapkan oleh Allah dalam bidang tajrid, tapi masih merasa kurang terhadap dunia, dan berkeinginan untuk menempati bidang usaha (asbab), maka hal ini merupakan suatu kemunduran bagi orang yang tajrid. Karena hakikatnya tingkatan tajrid adalah lebih tinggi dari derajat asbab.

Sebagai manusia yang berakal dan beriman, kita dituntut untuk mengatahui potensi kita dan menerima karunia Allah SWT tersebut, apakah digolongkan di bidang tajrid atau di bidang asbab kemudian menjadikan penempatan Allah SWT tersebut sebagai aset untuk mencari ridha dan pahala dari-Nya.

Imam Al Ghazali dalam Ihya 'Ulumiddin memberikan pencerahan bagaimana aktifitas potensi yang ada dalam diri kita sebagai aset untuk mendapatkan pahala akhirat. Sehingga apapun aktifitas kita akan bernilai ibadah dan mendapatkan ridha Allah.

Beliau mengatakan bahwasanya orang yang mencari kebahagian dan pahala ahkirat, dalam menempuhnya tidak lepas dari 6 keadaan dan potensi: Sebagai ahli ibadah, sebagai orang yang berilmu dan menularkan ilmunya, sebagai pelajar, sebagai pejabat atau pemimpin, sebagai orang yang berprofesi dan bekerja, dan sebagai orang yang muwahhid yang tenggelam di dalam cinta kepada Allah semata. 
Adapun ahli ibadah adalah orang yang mengkhususkan diri hanya beribadah kepada Allah, ia tidak memiliki kesibukan lain selain dari pada itu, sehingga apabila ia meniggalkan ibadah maka ia akan menganggur. Ia habiskan waktunya hanya untuk menjalankan berbagai macam ibadah, baik dengan shalat, membaca quran, berdzikir, ataupun bertasbih. Pada masa Rasulullah ada sekelompok sahabat yang berdzikir sebanyak 12.000 tasbih sehari, ada yang berdzikir sebanyak 30.000 tasbih sehari, ada yang shalat sebanyak 300 rakaat bahkan ada yang shalat sebanyak 600 hingga 1.000 rakaat tiap harinya, mereka paling sedikit mengerjakan sebanyak 100 rakaat dalam sehari semalam. Sebagian mereka ada yang kesibukannya hanya membaca Al Quran, sehingga dalam sehari dapat membaca quran dengan sekali khatam bahkan ada yang dapat membaca qura dengan dua kali khatam tiap harinya. Sebagian mereka ada yang sibuk bertafakkur dalam memahami satu ayat saja, sebagia mereka ada yang thawaf di ka'bah sebanyak 70 kali putaran perharinya dan 70 kali putaran dalam semalam dan mengkhatamkan quran dua kali dalam sehari semalam, dan masih banyak lagi dari mereka yang kesibukannya hanya beribadah dan perpindahan dari ibadah yang satu ke ibadah yang lain.

Yang paling utama bagi ahli ibadah ialah hanya menyibukkan diri dalam beribadah dan dalam majelis dzikir.

Rasulullah SAW bersabda: 


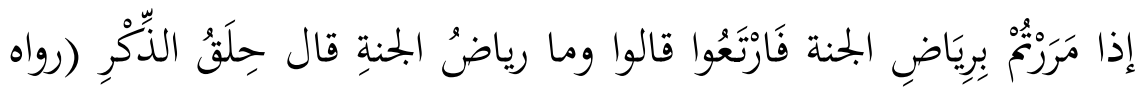
أحمد، والترمذى، وأبو يعلى، والبيهقى في شعب الإيمان عن أنس)

"Jika kalian melalui padang rumput surga, maka merumputlah disitu, mereka (para sahabat) bertanya : 'Apakah padang rumput surga itu?', Beliau menjawab : 'yaitu halaqahhalaqah dzikir'"(HR Ahmad, Tirmidzi, Abu Ya'la, dan Baihaqi)

Dalam hadits lain Rasulullah bersabda:

$$
\begin{aligned}
& \text { إذا مررتم برياضِ الجنةِِ فاجلسوا إليهم قالوا يا رسولَ اللهِ وما رياضُ الجننة } \\
& \text { قال أهلو الذكرِ (ابن شاهين عن أبى هريرة) }
\end{aligned}
$$

"Jika kalian melalui kebun-kebun surga, maka duduklah bersama mereka. Para Sahabat bertanya : apakah kebun-kebun surga itu ya Rasulullah?, beliau menjawab : yaitu ahli dzikir" (HR Ibnu Syahin)

Yang kedua adalah Orang yang alim (berilmu dan menularkan ilmunya) yaitu orang memberikan manfaat kepada manusia dengan ilmunya melaui fatwanya, pengajarannya, ataupun melalui tulisan-tulisannya. Menyibukkan diri dalam hal-hal yang demikian baginya adalah yang paling utama. Dengan syarat tujuan dari pengajarannya adalah sebagai wasilah untuk mencapai ridha Allah bukan karena tujuan duniawi.

Yang dimaksud dengan ilmu yang diajarkan di sini adalah ilmu yang bisa memberikan motivasi kepada manusia dalam beramal dan menjadikan mereka mementingkan kepentingan ukhrawi dari pada kepentingan 
duniawi atau menolong mereka dalam menempuh jalan menuju kebahagiaan akhirat, bukan ilmu yang menjadikan mereka semakin cinta harta, pangkat dan ketenaran.

Allah SWT berfirman:

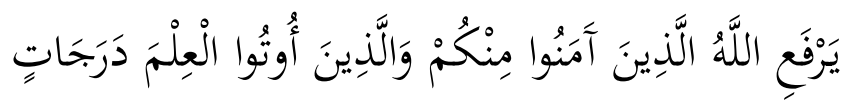

"Niscaya Allah akan meninggikan orang-orang yang beriman di antaramu dan orang-orang yang diberi ilmu pengetahuan beberapa derajat." (Al Mujadalah : 11)

Ibnu Abbas ra berkata: Ulama memiliki derajat diatas orang beriman lainnya dengan 700 derajat, dan antara derajat yang satu dengan yang lainnya adalah 700 tahun perjalanan.

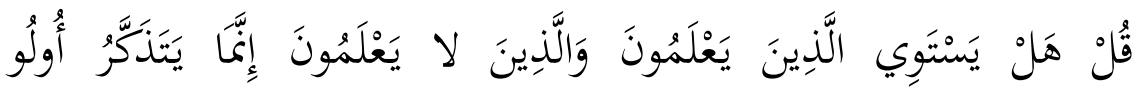
الألَبَابِ

"Katakanlah: "Adakah sama orang-orang yang mengetahui dengan orang-orang yang tidak mengetahui?" Sesungguhnya orang yang berakallah yang dapat menerima pelajaran." (Azzumar : 9)

أقرب الناس من درجة النبوة أهل الجهاد وأهل العلم لأن أهل الجهاد يجاهدون على ما جاءت به الرسل وأما أهل العلم فدلوا الناس على ما جاءت به الأنبياء (الديلمى عن ابن عباس)

"Manusia yang paling dekat dari derajat nubuwah adalah ahli ilmu dan ahli jihad, dikarenakan ahli jihad berjuang atas perkara yang dibawa oleh para rasul, sedangkan ahli ilmu mereka 
memberikan petunjuk kepada manusia atas perkara yang dibawa oleh para nabi" (HR Ad Dailami dari Ibnu Abbas ra)

Yang ketiga adalah Pelajar, Yaitu orang yang mencari ilmu karena Allah SWT. Maka kesibukannya dalam belajar itu lebih utama baginya dari pada menyibukkan diri berdzikir dan mengerjakan nawafil, tetapi hendaknya ia tidak mengosongkan dirinya untuk berwirid dari dzikir setiap harinya, karena yang demikian itu akan membantu dan memberikan kemudahan kepada dirinya dalam menempuh perjalannya untuk mencari ilmu. Bahkan bagi orang awam, duduk di majelis ilmu dan pengajian yang berisi nasehat-nasehat lebih utama baginya dari pada menyibukkan diri hanya berdzikir.

Rasulullah SAW bersabda:

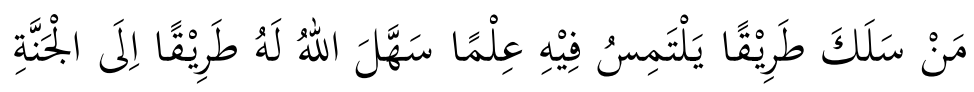

"Barangsiapa berjalan mencari ilmu maka akan Allah mudahkan untuknya jalan menuju surga. "

Rasulullah SAW bersabda:

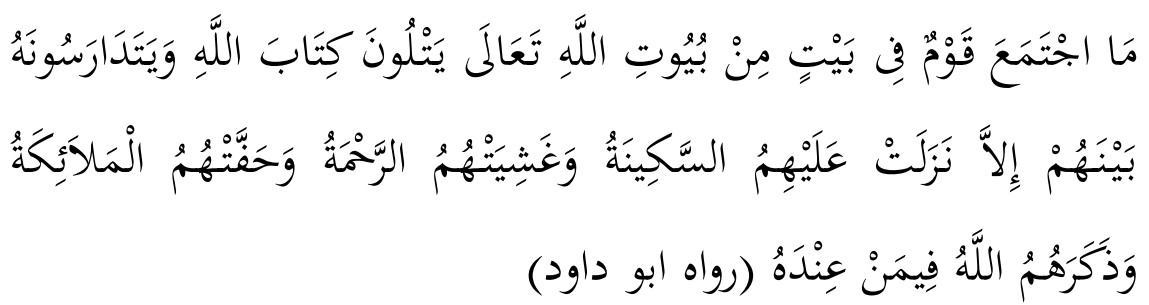

"Tidak berkumpul suatu kaum di salah satu rumah dari rumah-rumah Allah, mereka membaca kitab Allah dan saling mengajarkannya di antara mereka, kecuali turun atas mereka ketenangan, dicucuri rahmat, dikelilingi oleh malaikat dan disebut- 
sebut oleh Allah di kalangan malaikat-malaikat yang di sisi-Nya (HR Abu Dawud)

Sayyidina Umar ra berkata: “Sesungguhnya seorang laki-laki keluar dari rumahnya, sedangkan ia mempunyai dosa sebesar gunung tahamah. Maka apabila ia mendengarkan orang yang alim kemudian ia takut dan meminta perlindungan Allah, dan taubat dari dosa-dosanya, maka ia pulang ke rumahnya dengan tanpa dosa sedikitpun. Maka janganlah sekali-kali kalian memisahkan diri dari majelis ulama', karena Allah SWT tidak menciptakan di muka bumi ini satu tanah pun yang lebih mulia dari pada majelis ulama'"

'Atha bin Abu Ribah ra berkata: "menghadiri majelis ilmu menghapuskan 70 majelis lalai dan senda gurau)"

Yang ke empat adalah Orang yang berprofesi, yaitu orang yang sangat memerlukan suatu pekerjaan untuk keluarganya, karena ia tidak mungkin meninggalkan keluarganya dan menghabiskan waktunya hanya untuk beribadah, bahkan kesibukannya adalah bekerja, pergi ke pasar dan sibuk melakukan usaha, begitulah waktu-waktu di laluinya. Tetapi hendaknya bagi orang seperti ini tidak lupa untuk berdzikir kepada Allah di sela-sela ia bekerja dengan hatinya, tetap melakukan dzikir dan tasbih dengan teratur da membaca Al Quran, karena yang demikian itu dapat mengumpulkan dua amal dan tetap tidak meninggalkan yang penting. Ketika ia telah selesai dari pekerjaan dan istirahat maka hendaknya ia kembali melakukan ibadah dan bersedekah. Karena orang yang menekuni suatu usaha dan kemudian ia bersedekah dari 
rejeki yang lebih dari kebutuhannya, maka hal ini lebih utama dari ibadah-ibadah yang lain. Karena ibadah yang manfaatnya mengalir kepada orang lain lebih utama dari ibadah yang manfaatnya hanya untuk sendiri. Oleh karena itu, bekerja dan bersedekah dengan niat yang demikian hakikatnya adalah ibadah yang mendekatkan diri kepada Allah SWT.

Yang kelima adalah Penguasa atau pemimpin, seperti seorang pemimpin, imam, hakim, dan setiap orang yang bertanggung jawab terhadap kemaslahatan kaum muslimin. Pekerjaanya adalah menunaikan hajat kaum muslimin dan keinginan mereka, sesuai dengan yang telah disyariatkan dan tidak melanggar syara' dan dengan niat yang ikhlas. Maka yang demikian ini lebih utama dari pada menyibukkan diri dengan berwirid. Ia hanya disibukkan dengan menunaikan hak-hak manusia pada siang hari, dengan tanpa meninggalka ibadah fardhu dan rawatib. Dan melakukan ibadah pada malam harinya. Sebagaimana yang dilakukan sayyidina Umar ra. Kata beliau: “jika aku tidur pada siang hari, maka aku telah melalaikan hak-hak kaum muslimin, dan jika aku tidur pada malam hari, maka aku telah melalaikan hakku.

Yang keenam adalah Muwahhid yang tenggelam dalam keesaan Allah, yaitu orang yang pikirannya hanya satu, hanya mencintai Allah, hanya takut kepada Allah. Tidak meminta rejeki selain dari Allah. Maka barangsiapa yang mecapai derajat seperti ini maka ia tidak memerlukan banyaknya jenis ibadah, melainkan jenis wiridnya hanya satu selain dari ibadah-ibadah fardhu dan rawatibnya, yaitu 
hadirnya hati bersama Allah SWT dalam setiap keadaan, tidak terbesit dalam hatinya sesuatupun selain Allah SWT, dalam pandangan dan pendengarannya hanya ada 'ibrah, tafakkur dan bertambahnya iman kepada Allah. Maka derajat ini adalah yang paling tinggi derajatnya, derahat para Shadiqin. Dan tidak akan sampai pada derajat ini kecuali setelah melalui derajat-derajat yang paling rendah dan dengan laithan dan proses yang cukup untuk mencapai derajat ini.

Demikianlah enam hal dan kesibukan yang telah dipaparkan oleh Syaikh Al Ghazali untuk mendapatkan kebahagiaan di akhirat. Sekarang, bagaimana apa yang ada dalam diri kita, potensi yang kita miliki agar menghasilkan nilai-nilai pahala dan ridha Allah SWT, dengan cara menjalankan apa yang ada dalam diri kita ataupun potensi kita sebaik mungkin, menjadikan keterbatasan yang kita miliki sebagai aset untuk berkompetensi dalam kebaikan dan pencerminan dari nilai-nilai ukhrawi. Allah menciptakan manusia berbeda-beda profesi dan menjadikan kepada mereka aturan dan jalan yang terang, agar mereka berlomba-lomba dalam kebaikan menurut kemampuan mereka.

Allah SWT berfirman:

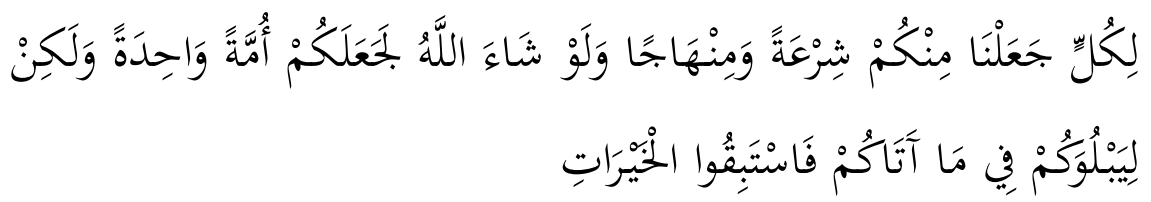

"Untuk tiap-tiap umat di antara kamu, Kami berikan aturan dan jalan yang terang. Sekiranya Allah menghendaki, 
niscaya kamu dijadikan-Nya satu umat (saja), tetapi Allah hendak menguji kamu terhadap pemberian-Nya kepadamu, maka berlomba-lombalah berbuat kebajikan" (QS Al Maidah : 48)*

Kitab rujukan : Ihya' Ulumiddin-Imam Al Ghazali, Tanwirul Qulub-Syaikh Muhammad Amin Al Kurdi, Hikam-Syaikh Ibnu Athaillah. 